\title{
Lymphatic vascular morphogenesis in development, physiology, and disease
}

\author{
Stefan Schulte-Merker, ${ }^{1,2,3}$ Amélie Sabine, ${ }^{4,5,6}$ and Tatiana V. Petrova ${ }^{4,5,6}$ \\ 'Hubrecht Institute, Royal Netherlands Academy of Arts and Sciences, and University Medical Centre, 3584 CT Utrecht, Netherlands \\ ${ }^{2}$ Centre for Biomedical Genetics, 3584 CT Utrecht, Netherlands \\ ${ }^{3}$ Experimental Zoology Group, Department of Animal Sciences, Wageningen University, 6709 PG Wageningen, Netherlands \\ ${ }^{4}$ Division of Experimental Oncology, Multidisciplinary Oncology Center, ${ }^{5}$ Central University Hospital, and ${ }^{6}$ Department of Biochemistry, University of Lausanne, \\ $\mathrm{CH}-1066$ Epalinges, Switzerland
}

The lymphatic vasculature constitutes a highly specialized part of the vascular system that is essential for the maintenance of interstitial fluid balance, uptake of dietary fat, and immune response. Recently, there has been an increased awareness of the importance of lymphatic vessels in many common pathological conditions, such as tumor cell dissemination and chronic inflammation. Studies of embryonic development and genetically engineered animal models coupled with the discovery of mutations underlying human lymphedema syndromes have contributed to our understanding of mechanisms regulating normal and pathological lymphatic morphogenesis. It is now crucial to use this knowledge for the development of novel therapies for human diseases.

\section{Introduction}

The lymphatic vascular system serves key physiological functions: it maintains fluid homeostasis by absorbing water and macromolecules from the interstitium, enables uptake of dietary lipids and vitamins in the intestine, and serves as a trafficking route for immune cells. The lymphatic vasculature consists of a highly branched network of capillaries and ducts that is present in most organs with the exception of the central nervous system and avascular tissues, such as cartilage. Unlike the blood vasculature, the lymphatic vasculature is blind ending (Fig. $1 \mathrm{~A}$ ): its small capillaries funnel first into precollecting and larger collecting vessels and then into the thoracic duct or the right lymphatic trunk, which drains lymph into the subclavian veins.

Correspondence to Tatiana V. Petrova: tatiana.petrova@unil.ch

Abbreviations used in this paper: BEC, blood endothelial cell; FN, fibronectin; GD, Gorham disease; HLT, hypotrichosis-lymphedema-telangiectasia syndrome; KS, Kaposi sarcoma; KSHV, KS-associated herpes virus; LAM, lymphangioleiomyomatosis; LEC, lymphatic endothelial cell; LD, lymphedemadistichiasis syndrome; mTOR, mammalian target of rapamycin; NFAT, nuclear factor of activated T cells; PI, phosphoinositide; SMC, smooth muscle cell; Syk, spleen tyrosine kinase.
Malfunctioning of the lymphatic vasculature results in lymphedema formation and compromises immune function. In the past decade, tremendous progress has been achieved in understanding the mechanisms regulating the morphogenesis of lymphatic vasculature, mainly accomplished by genetically modified mouse models and discovery of mutations responsible for human lymphedema syndromes. In addition, models, such as zebrafish and frog tadpoles, are emerging as powerful tools for studying lymphatic vascular development. In this review, we will summarize the main mechanisms underlying the development of lymphatic vasculature and present an overview of several human diseases that are associated with lymphatic vessel abnormalities.

\section{Mechanisms of lymph transport}

The structure of the different lymphatic vascular compartments, such as capillaries, precollecting, and collecting lymphatic vessels, reflects its dual role in fluid absorption and lymph transport. We will briefly present the main aspects of lymph transport, which have been documented in more detail in recent reviews (Dejana et al., 2009; Zawieja, 2009).

Fluid and cell uptake by lymphatic capillaries. Lymphatic capillary endothelium has a unique junctional organization (Baluk et al., 2007; Dejana et al., 2009). Oak leaf-shaped endothelial cells are connected by discontinuous buttonlike junctions. Free overlapping cell edges anchored on each side by these junctions form "flap valves" (Fig. 1, B and C) through which fluid flows unidirectionally along pressure gradients from the interstitium into the capillary lumen. Actively sprouting lymphatic capillaries have continuous cell-cell junctions, suggesting buttonlike junctions as characteristics of quiescent and functional lymphatic capillary endothelium (Baluk et al., 2007). Lymphatic capillaries lack mural cells and connect to the ECM via anchoring filaments (Leak and Burke, 1968), which prevent the collapse of capillaries upon the increase of interstitial pressure (Fig. 1 B).

(c) 2011 Schulte-Merker et al. This article is distributed under the terms of an AttributionNoncommercial-Share Alike-No Mirror Sites license for the first six months after the publication date (see http://www.rupress.org/terms). After six months it is available under a Creative Commons License (Attribution-Noncommercial-Share Alike 3.0 Unported license, as described at http://creativecommons.org/licenses/by-nc-sa/3.0/). 
A

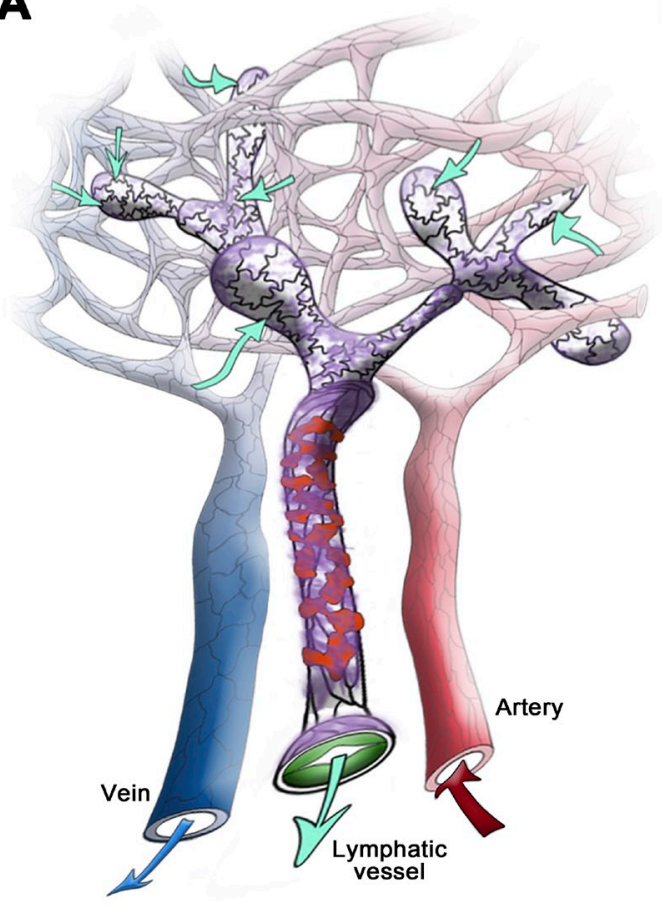

C

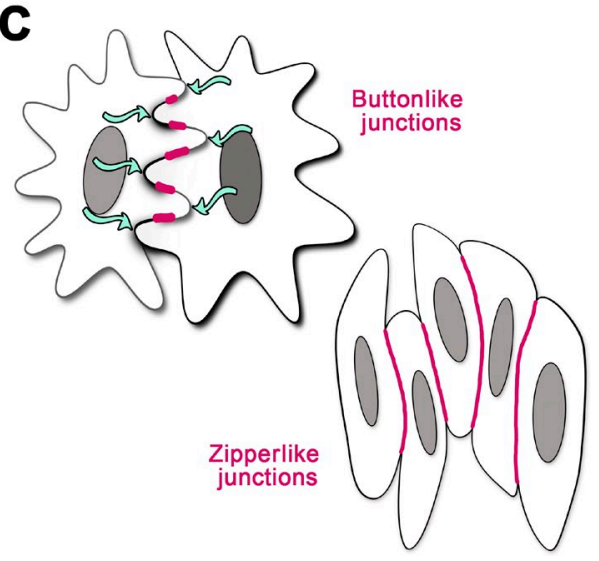

B

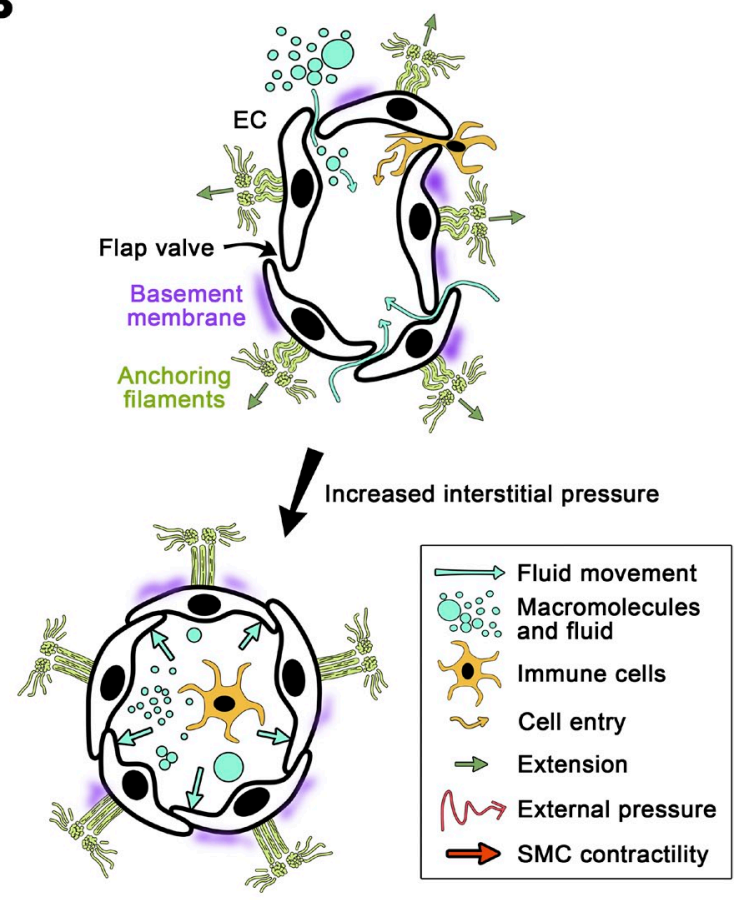

D

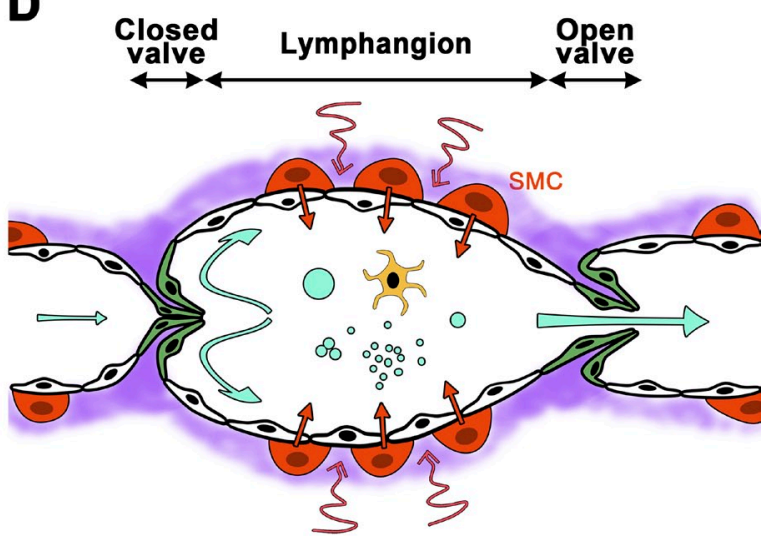

Figure 1. Organization of lymphatic vasculature. (A) The lymphatic vasculature resorbs fluid, macromolecules, and cells from the interstitium. (B) Mechanism of lymph formation in capillaries. Interstitial components penetrate lymphatic capillaries via openings between LECs. The specialized structure of such openings prevents the return of lymph back to the interstitium. Anchoring filaments attach LECs to the ECM and prevent vessel collapse under conditions of increased interstitial pressure (black arrow). (C) Junctional organization of LECs in lymphatic capillaries and collecting vessels. Both "buttons" and "zippers" share a repertoire of adherens and tight junction-associated proteins (e.g., VE-cadherin, zonula occludens-1, occludin, and claudin-5). The main difference between them resides in their organization (Baluk et al., 2007). (D) Mechanism of lymph propulsion in collecting vessels. Coordinated opening and closure of lymphatic valves is important for efficient lymph transport. SMCs covering each lymphangion possess intrinsic contractile activity. EC, endothelial cell.

Shear stress generated by transcapillary fluid flow regulates the expression of junctional proteins, up-regulates leukocyte adhesion molecules ICAM-1 and E-selectin, and promotes secretion of chemokine CCL21, mediating dendritic cell migration (Miteva et al., 2010). Thus, mechanical stimulation may be important for immune surveillance function of lymphatic vasculature. Dendritic cells first squeeze through pores that punctuate the sparse basement membrane of lymphatic capillaries and, subsequently, reach the lumen through interendothelial flap valves (Fig. 1 B; Pflicke and Sixt, 2009). They are then transported toward the draining lymph nodes where they induce immune responses.
Transport of lymph by collecting vessels. Lymph from lymphatic capillaries is first drained into the precollecting lymphatic vessels that have both lymphatic capillary (oak leaf-shaped lymphatic endothelial cells [LECs]) and collecting lymphatic vessel characteristics (valves). Collecting lymphatic vessels consist of a series of functional units, called lymphangions, separated by intraluminal valves, which ensure unidirectional lymph flow (Fig. 1 D). Collecting vessels are covered with a continuous basement membrane and smooth muscle cells (SMCs). Endothelial cells in collecting vessels are elongated and connected by continuous zipperlike junctions (Fig. 1 C). Continuous junctions and basement membrane prevent leakage of lymph during its transport. 


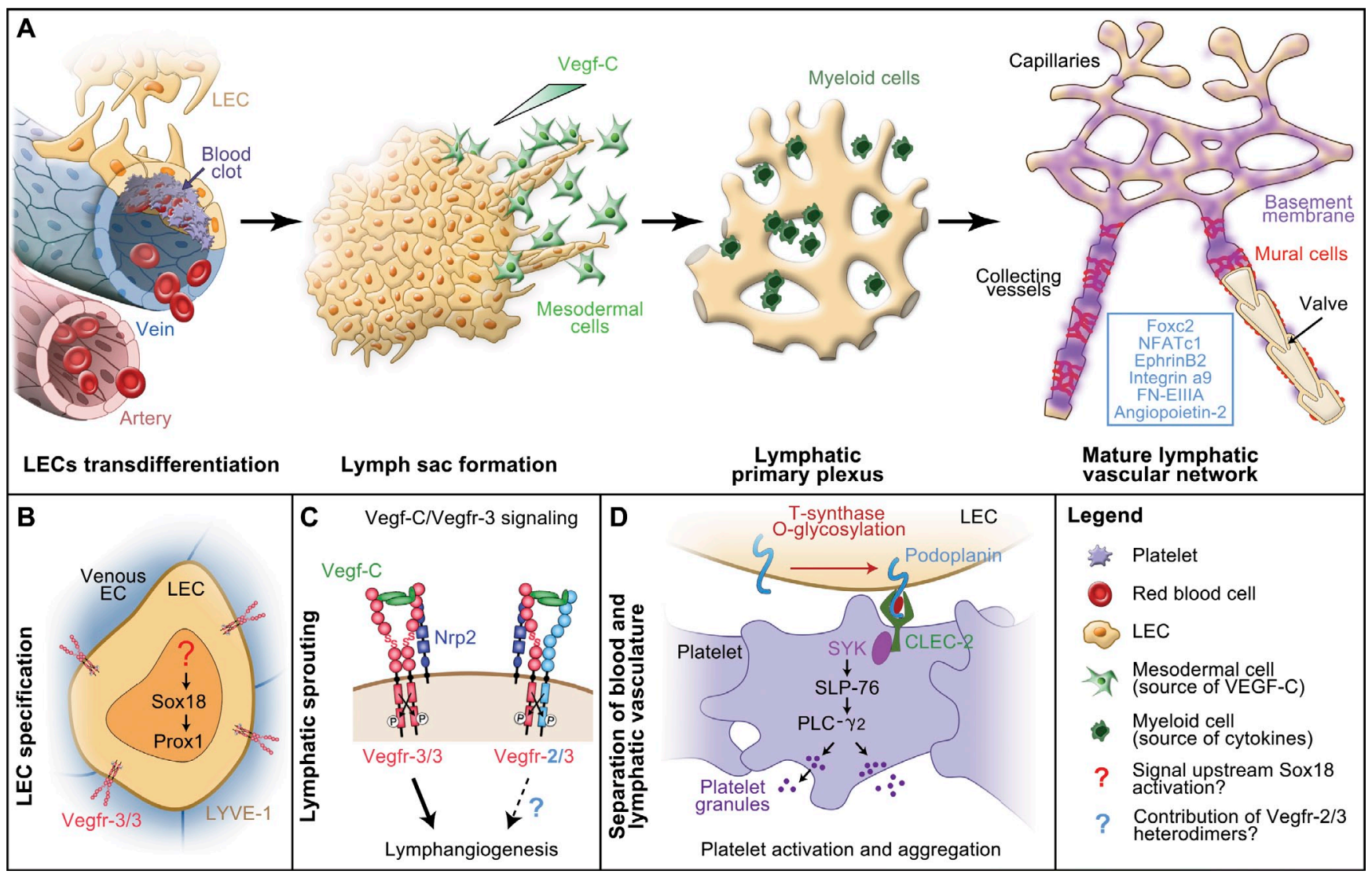

Figure 2. Main steps of mammalian lymphatic vascular development. (A) LECs are specified in embryonic veins, from where they sprout toward Vegf-cproducing mesodermal cells and aggregate to form lymph sacs. Further sprouting produces the lymphatic primary plexus composed of capillary-like vessels. Myeloid cells produce cytokines and regulate lymphatic vascular morphogenesis. Primary plexus is further remodeled to form collecting, precollecting, and capillary compartments. Precollecting and collecting lymphatic vessels have intraluminal valves and basement membrane coverage. Collecting lymphatic vessels are surrounded by SMCs (red). (box) Genes important for collecting lymphatic vessel development. (B) LYVE-1 is the earliest known LEC marker. The transcription factor Proxl is essential for the establishment of LEC identity, and its expression is controlled by Sox 18. (C) Signaling via Vegf-c and Vegfr-3 regulates LEC sprouting and proliferation. The role of Vegfr-2-Vegfr-3 heterodimers and participation of Nrp2 in the Vegfr-2-Vegfr-3 complex are not fully understood. (D) Separation of lymphatic and blood vasculature requires platelet aggregation (also see Table I). Interaction of podoplanin on LECs and CLEC-2 on platelets triggers the Syk-, Slp76-, and PLC-y2-dependent signaling cascade leading to platelet aggregation. O-glycosylation by T-synthase is important for podoplanin function.

Lymphatic valves contain two semilunar leaflets, which are covered on both sides by a specialized endothelium anchored to the ECM core (Lauweryns and Boussauw, 1973). High lymph pressure upstream of a valve opens the valve and enables lymph flow, whereas reverse flow pushes the leaflets against each other and closes the valve (Fig. 1 D). Therefore, opening and closing of the valve depend on periodic changes in fluid pressure within collecting vessels. The number of valves per vessel segment varies depending on tissue type, being generally highest in organs with high hydrostatic pressure, e.g., legs in humans (Földi et al., 2006).

Cyclical compression and expansion of lymphatic vessels by surrounding tissues and intrinsic pump forces generated by the spontaneous phasic contraction of SMCs regulate lymph propulsion (Zawieja, 2009). The origin of lymphatic SMCs is unknown, but they contain both smooth and striated muscle contractile proteins and, thus, differ from arteriole SMCs (Muthuchamy et al., 2003). Nitric oxide, hormones, and prostanoids control SMC contractions (Zawieja, 2009). In amphibians and reptiles, specialized pulsatile muscular organs or lymph hearts located at the junctions of the lymphatic and venous systems control lymph flow (Kampmeier, 1969).

\section{Lymphatic vascular morphogenesis}

Lymphatic vascular development requires transdifferentiation of venous endothelial cells toward the lymphatic endothelial phenotype, separation of blood and lymphatic vasculature, sprouting of lymphatic vessels, and lymphatic vascular maturation (Fig. 2 A). Over 20 genes orchestrate these processes in mice (Table I), and recently, lymphangiogenesis has also been examined in lower vertebrates, such as fish and frogs.

Establishment of LEC identity and Iymphatic sprouting. Lymphatic vessels stem from preexisting blood vessels. Elegant lineage tracing by Srinivasan et al. (2007) demonstrated the venous origin of the mammalian lymphatic vasculature as previously proposed (Sabin, 1902; Kaipainen et al., 1995). The venous origin of LECs has been confirmed in Xenopus laevis and zebrafish as shown by real-time imaging in the latter and, therefore, appears to be evolutionary conserved (Ny et al., 2005; Yaniv et al., 2006; Hogan et al., 2009a). 
Table I. Knockout or mutant mouse models and their phenotypes according to stages of lymphatic vascular morphogenesis

\begin{tabular}{|c|c|c|c|}
\hline Gene symbol & Function & Lymphatic vascular phenotype & Expression pattern \\
\hline \multicolumn{4}{|l|}{ LEC differentiation } \\
\hline Prox 1 & Transcription factor & $\begin{array}{l}\text { No LECs }(-/-) \text {, chylous ascites }(+/-) \text {; } \\
\text { loss of LEC identity, chylous ascites, obesity } \\
\text { (Prox } T^{f / f} \text {; Tie2-Cre; Wigle et al., 1999; } \\
\text { Harvey et al., 2005; Johnson et al., 2008) }\end{array}$ & $\begin{array}{l}\text { LECs, hepatocytes, lens fiber } \\
\text { cells, pancreatic, lung, } \\
\text { and intestinal endocrine } \\
\text { cells, skeletal muscle, } \\
\text { cardiomyocytes }\end{array}$ \\
\hline Sox 18 & Transcription factor & $\begin{array}{l}\text { No LECs(-/-, on C57BL/6J background); } \\
\text { abnormal patterning (+/-); edema and chylous } \\
\text { ascites (heterozygous ragged mutants; } \\
\text { Pennisi et al., 2000; François et al., 2008) }\end{array}$ & Endothelial cells \\
\hline Coup-TFII (NR2F2) & Transcription factor & $\begin{array}{l}\text { No LECs }(-/- \text {, deletion at or before E9.5); } \\
\text { edema, loss of LEC identity, and sprouting } \\
\text { (-/-, deletion at later stages; Lin et al., 2010; } \\
\text { Srinivasan et al., 2010) }\end{array}$ & Endothelial cells and SMCs \\
\hline \multicolumn{4}{|l|}{ Lymphangiogenesis } \\
\hline \multicolumn{4}{|l|}{ Vegf-c-Vegfr-3 pathway } \\
\hline Vegfr3 & Receptor tyrosine kinase & $\begin{array}{l}\text { Hypoplasia, chylous ascites (+/Chy, ENU-induced } \\
\text { mutation, loss of tyrosine kinase activity; } \\
\text { Karkkainen et al., 2001); lymph sacs formed } \\
\text { and defective sprouting (homozygous deletion of } \\
\text { ligand-binding domain; Zhang et al., 2010) }\end{array}$ & $\begin{array}{l}\text { LECs, fenestrated blood } \\
\text { vascular endothelial cells, } \\
\text { blood vascular endothelial } \\
\text { cells in tumors and during } \\
\text { early embryogenesis }\end{array}$ \\
\hline Vegfc & $\begin{array}{l}\text { Growth factor, } \\
\text { ligand for Vegfr-3 }\end{array}$ & $\begin{array}{l}\text { No sprouting of LECs from veins }(-/-) \text {; } \\
\text { hypoplasia, chylous ascites (+/-; Karkkainen } \\
\text { et al., 2003) }\end{array}$ & $\begin{array}{l}\text { Macrophages, SMCs, } \\
\text { and subpopulation of } \\
\text { mesenchymal cells during } \\
\text { development }\end{array}$ \\
\hline Nrp2 & $\begin{array}{l}\text { Coreceptor of Vegfr-3 } \\
\text { and semaphorins }\end{array}$ & $\begin{array}{l}\text { Transient capillary hypoplasia, defective sprouting } \\
(-/- \text {; Yuan et al., 2002; Xu et al., 2010) }\end{array}$ & $\begin{array}{l}\text { Venous and lymphatic } \\
\text { endothelial cells }\end{array}$ \\
\hline Racl & Rho GTPase & $\begin{array}{l}\text { Abnormal migration of LECs from veins }\left(\operatorname{Rac}^{f / f}\right. \\
\text { Tie 1-Cre; D'Amico et al., 2009) }\end{array}$ & Broad \\
\hline Clp24 & Transmembrane protein & $\begin{array}{l}\text { Lymphangiectasia, ectopic mural cells } \\
\left(\text { Clp2 } 24^{-/-} ; C l p 24^{-/-} ; \text {Vegfr } 3^{\text {lacz/s }+} \text { and } C l p 24^{-/-} ;\right. \\
\text {Vegfr2 } 2^{\text {lacz/+ }} \text {; Saharinen et al., 2010) }\end{array}$ & Endothelial cells \\
\hline$T b \times l$ & Transcription factor & $\begin{array}{l}\text { Hypoplasia and chylous ascites }\left(T b \times l^{f / f}\right. \\
\text { Tie2-Cre; Chen et al., 2010) }\end{array}$ & Vascular, including LECs \\
\hline Ptpn 14 (gene trap) & Protein tyrosine phosphatase & $\begin{array}{l}\text { Hyperplasia of dermal lymphatic vessels in } \\
14 \% \text { of mutants, paw or periorbital edema } \\
\text { (Au et al., 2010) }\end{array}$ & Broad, including LECs \\
\hline \multicolumn{4}{|c|}{ Adrenomedullin signaling } \\
\hline $\begin{array}{l}\text { Adm } \\
\quad \text { (adrenomedullin) }\end{array}$ & $\begin{array}{l}\text { Peptide vasodilator, } \\
\text { ligand for Calcrl }\end{array}$ & $\begin{array}{l}\text { Hypoplasia of jugular lymph sacs, decreased LEC } \\
\text { proliferation, edema (-/-, Calcrl }{ }^{\text {oxP//-;Tie2-Cre; }} \\
\text { Fritz-Six et al., 2008) }\end{array}$ & $\begin{array}{l}\text { Adrenal medulla, vascular } \\
\text { SMCs and endothelial cells, } \\
\text { cardiomyocytes }\end{array}$ \\
\hline Ramp2 & Coreceptor of Calcrl & $\begin{array}{l}\text { Hypoplasia of jugular lymph sacs, decreased LEC } \\
\text { proliferation, edema (-/-, Calcrl }{ }^{\text {LoxP/--Tie2-Cre; }} \\
\text { Fritz-Six et al., 2008) }\end{array}$ & Broad, including LECs \\
\hline $\begin{array}{l}\text { Calcrl (calcitonin recep- } \\
\text { tor-like) }\end{array}$ & $\begin{array}{l}G \text { protein-coupled receptor } \\
\text { of adrenomedullin }\end{array}$ & $\begin{array}{l}\text { Hypoplasia of jugular lymph sacs, decreased LEC } \\
\text { proliferation, edema (-/-, Calcr }{ }^{\text {LoxP/-; Tie2-Cre; }} \\
\text { Fritz-Six et al., 2008) }\end{array}$ & Broad, including LECs \\
\hline \multicolumn{4}{|c|}{$x_{0}$} \\
\hline Vezf & Transcription factor & $\begin{array}{l}\text { Transient jugular lymphatic hypervascularization } \\
(+/- \text {; Kuhnert et al., 2005) }\end{array}$ & Broad \\
\hline Tiel & Receptor tyrosine kinase & $\begin{array}{l}\text { Abnormal lymphatic patterning, dilated and } \\
\text { disorganized lymphatic vessels (hypomorphic mice } \\
\text { on outbred background; D'Amico et al., 2010) }\end{array}$ & $\begin{array}{l}\text { Endothelial and hematopoietic } \\
\text { cells }\end{array}$ \\
\hline \multicolumn{4}{|c|}{ Separation of blood and lymphatic vessels } \\
\hline \multicolumn{4}{|c|}{ Platelet development } \\
\hline Meis 1 & Transcription factor & $\begin{array}{l}\text { Blood-filled lymphatic vessels (-/-; Carramolino } \\
\text { et al., 2010) }\end{array}$ & $\begin{array}{l}\text { Broad, including developing } \\
\text { hematopoietic cells }\end{array}$ \\
\hline \multicolumn{4}{|l|}{ Platelet aggregation } \\
\hline Slp76 & Adaptor protein & $\begin{array}{l}\text { Blood-filled lymphatic vessels, chylous ascites } \\
\quad(-/- \text {; Abtahian et al., 2003) }\end{array}$ & Hematopoietic cells \\
\hline
\end{tabular}


Table I (continued). Knockout or mutant mouse models and their phenotypes according to stages of lymphatic vascular morphogenesis

\begin{tabular}{|c|c|c|c|}
\hline Gene symbol & Function & Lymphatic vascular phenotype & Expression pattern \\
\hline Plcg2 & $\begin{array}{l}\text { Phospholipase C, hydrolysis of } \\
\text { phospholipids }\end{array}$ & $\begin{array}{l}\text { Blood-filled lymphatic vessels, chylous ascites } \\
\quad(-/-; \text { Ichise et al., 2009) }\end{array}$ & Broad \\
\hline Pdpn (podoplanin) & Transmembrane glycoprotein & $\begin{array}{l}\text { Lymphangiectasia, abnormal lymph transport, } \\
\text { lymphedema, blood-filled lymphatic vessels } \\
\text { (-/-; Schacht et al., 2003; Bertozzi et al., 2010; } \\
\text { Uhrin et al., 2010) }\end{array}$ & $\begin{array}{l}\text { LECs, keratinocytes, alveolar } \\
\text { type II cells, podocytes }\end{array}$ \\
\hline $\begin{array}{l}\text { Clgaltr (encodes T-syn- } \\
\text { thetase) }\end{array}$ & $\begin{array}{l}\text { Glycosyltransferase, biosynthesis } \\
\text { of core-1-derived O-glycans }\end{array}$ & $\begin{array}{l}\text { Blood-filled lymphatic vessels, decreased levels of } \\
\text { podoplanin (-/-; Fu et al., 2008) }\end{array}$ & $\begin{array}{l}\text { Endothelial and hematopoietic } \\
\text { cells }\end{array}$ \\
\hline Clec-2 & C-type lectin receptor & $\begin{array}{l}\text { Blood-filled lymphatic vessels (-/-; Bertozzi et al., } \\
\text { 2010; Suzuki-Inove et al., 2010) }\end{array}$ & $\begin{array}{l}\text { Platelets, peripheral blood } \\
\text { neutrophils }\end{array}$ \\
\hline Syk & Nonreceptor tyrosine kinase & $\begin{array}{l}\text { Blood-filled lymphatic vessels, chylous ascites, } \\
\text { accumulation of myeloid cells in the dermis } \\
\left(-/-, \text { Syk } k^{f / f} \text {;vav-cre; Abtahian et al., 2003; }\right. \\
\text { Bertozzi et al., 2010; Böhmer et al., 2010) }\end{array}$ & \\
\hline \multicolumn{4}{|l|}{ Other } \\
\hline Spred1/Spred2 & Cytoplasmic adaptor proteins & $\begin{array}{l}\text { Blood-filled lymphatic vessels } \\
\quad \text { (Spred } 1^{-1-} ; \text { Spred } 2^{-1-} \text {; Taniguchi et al., 2007) }\end{array}$ & Broad, including LECs \\
\hline \multicolumn{4}{|c|}{ Remodeling, maturation, and valve morphogenesis } \\
\hline \multicolumn{4}{|c|}{ Tie/PI3-kinase signaling } \\
\hline Aktl & Ser/Thr kinase & $\begin{array}{l}\text { Capillary hypoplasia, valve agenesis, dilation, } \\
\text { and decreased SMC coverage of small collecting } \\
\text { lymphatic vessels (-/-; Zhou et al., 2010) }\end{array}$ & Broad \\
\hline Angpt2 & $\begin{array}{l}\text { Growth factor, ligand of Tie } \\
\text { receptor tyrosine kinases }\end{array}$ & $\begin{array}{l}\text { Hypoplasia, chylous ascites, defective remodeling, } \\
\text { and valve agenesis (-/-; Gale et al., 2002; } \\
\text { Dellinger et al., 2008) }\end{array}$ & $\begin{array}{l}\text { (Lymph) angiogenenic } \\
\text { endothelial cells, } \\
\text { hematopoietic cells }\end{array}$ \\
\hline $\begin{array}{l}\text { Pi3kca (mutation blocking } \\
\text { interaction with Ras) }\end{array}$ & $\begin{array}{l}\text { Catalytic p1 10 } \alpha \text { isoform of } \\
\text { PI3-kinase }\end{array}$ & $\begin{array}{l}\text { Chylous ascites, hypoplasia, impaired sprouting, } \\
\text { and branching of lymphatic capillaries } \\
(-/-; \text { Gupta et al., 2007) }\end{array}$ & Broad \\
\hline Pik3rl & $\begin{array}{l}\text { Regulatory subunits of class IA } \\
\text { PI3-kinases }\end{array}$ & $\begin{array}{l}\text { Chylous ascites, intestinal lymphangiectasia, } \\
\text { impaired sprouting, lymphatic, valve agenesis } \\
\text { (-/-; Mouta-Bellum et al., 2009) }\end{array}$ & Broad \\
\hline \multicolumn{4}{|c|}{ ECM assembly and interactions } \\
\hline $\operatorname{ltg} a 9$ & Adhesion & $\begin{array}{l}\text { Chylothorax, lymphatic valve agenesis } \\
(-/-; \text { Itga9f/f;Tie2-Cre and ltga9f/f; Cdh5 (PAC)- } \\
\text { CreERT2; Bazigou et al., 2009) }\end{array}$ & $\begin{array}{l}\text { BECs and LECs (highest in } \\
\text { valves), vascular SMCs }\end{array}$ \\
\hline $\begin{array}{l}\text { Fn } 1 \text { (removal of EDA } \\
\text { domain) }\end{array}$ & ECM component, ligand of $\operatorname{ltg}-\alpha 9$ & $\begin{array}{l}\text { Failure of lymphatic valve leaflet elongation } \\
(-/-; \text { Bazigou et al., 2009) }\end{array}$ & $\begin{array}{l}\text { Broad, including lymphatic } \\
\text { valves }\end{array}$ \\
\hline Emilin 1 & $\begin{array}{l}\text { Elastic microfibril-associated } \\
\text { protein }\end{array}$ & $\begin{array}{l}\text { Hyperplasia and abnormal patterning of lymphatic } \\
\text { vessels, reduction of anchoring filaments; } \\
\text { impaired lymph drainage, increased lymph } \\
\text { leakage (-/-; Danussi et al., 2008) }\end{array}$ & Broad, including LECs \\
\hline \multicolumn{4}{|l|}{ Other } \\
\hline Aspp 1 & Cytoplasmic adaptor protein & $\begin{array}{l}\text { Impaired assembly of lymphatic vessels and } \\
\text { collecting lymphatic vessel patterning, accumulation } \\
\text { of « lymphatic islands» }(-/- \text {; Hirashima et al., 2008) }\end{array}$ & Endothelial cells \\
\hline $\begin{array}{l}\text { Efnb2 (mutation of PDZ } \\
\text { binding site) }\end{array}$ & $\begin{array}{l}\text { Ligand of EphB receptor tyrosine } \\
\text { kinases }\end{array}$ & $\begin{array}{l}\text { Impaired sprouting of capillaries, agenesis of } \\
\text { lymphatic valves, ectopic mural cells, chylothorax, } \\
\text { retrograde lymph flow (-/-; Mäkinen et al., 2005) }\end{array}$ & $\begin{array}{l}\text { Arterial endothelial cells } \\
\text { and SMCs, LECs (highest } \\
\text { in the valves) }\end{array}$ \\
\hline Foxc2 & Transcription factor & $\begin{array}{l}\text { Impaired patterning of capillaries, no collecting } \\
\text { lymphatic vessels, agenesis of lymphatic valves, } \\
\text { ectopic mural cells, retrograde lymph flow } \\
\text { (-/-; Dagenais et al., 2004; Petrova et al., 2004; } \\
\text { Norrmén et al., 2009) }\end{array}$ & $\begin{array}{l}\text { Arterial endothelial cells } \\
\text { and SMCs, LECs (highest } \\
\text { in the valves) }\end{array}$ \\
\hline Elk3 (Net) & Transcription factor & $\begin{array}{l}\text { Lymphangiectasia, chylothorax } \\
(-/-; \text { Ayadi et al., 2001) }\end{array}$ & Endothelial cells \\
\hline $\begin{array}{l}\text { PU. } 1 \\
\text { Csfr } 1\end{array}$ & $\begin{array}{l}\text { Transcription factor } \\
\quad \text { receptor for M-CSF } 1\end{array}$ & $\begin{array}{l}\text { Hyperplasia and abnormal patterning of dermal } \\
\text { lymphatic vessels }(-/-; \text { Gordon et al., 2010) }\end{array}$ & $\begin{array}{l}\text { Hematopoietic cells (stage } \\
\text { dependent) }\end{array}$ \\
\hline
\end{tabular}

ENU, Nethyl-N-nitrosourea; PAC, P1-derived artificial chromosome. 
In mice, LECs are first specified in the anterior cardinal vein around embryonic day 9.5 (E9.5) when a subset of venous endothelial cells expresses the transcription factor Prox 1 and the lymphatic vessel hyaluronan receptor-1 (LYVE-1) in a polar manner (Fig. 2 B). Prox $1^{-1-}$ mice do not develop any lymphatic structures because of failed budding and sprouting of LECs (Wigle and Oliver, 1999). The transcription factor Sox18 induces Prox 1 expression, and Sox $18^{-/-}$mice develop edema caused by blockage of LEC development in the vein in certain genetic backgrounds (François et al., 2008). In vitro studies demonstrate SOX18 binding to the Proxl promoter and show that PROX1 can confer lymphatic identity to blood endothelial cells (BECs; Hong et al., 2002; Petrova et al., 2002; François et al., 2008). Thus, Sox 18 and Prox1 constitute an essential signaling axis for LEC specification. The nuclear receptor Coup-TFII (Lin et al., 2010; Srinivasan et al., 2010) has an earlier developmental role as a venous identity factor, but it also directly interacts with Prox1 (Lee et al., 2009; Yamazaki et al., 2009) and regulates the expression of LEC-specific genes, such as neuropilin-2 (Nrp2; Lin et al., 2010).

Prox1/LYVE-1-positive cells bud and migrate dorsolaterally from the central veins. They subsequently form the first bona fide lymphatic structures (jugular lymph sacs) in regions where lymphangiogenic growth factor Vegf-c is provided by the lateral mesoderm (Fig. 2 A; Karkkainen et al., 2003). This process occurs at several positions along the anterior-posterior axis of the early embryo and results in the formation of jugular, medial, and axial lymph sacs, which further give rise to a primary capillary plexus (Sabin, 1902). Vegf-c is critical in the process: Vegfc ${ }^{-/-}$ mice lack all lymphatic vasculature, and even $V e g \mathrm{C}^{+/-}$displays lymphatic hypoplasia (Karkkainen et al., 2003). The sprouting response of LECs to VEGF-C is mediated by the receptor tyrosine kinase VEGFR-3 and its nonsignaling transmembrane coreceptor Nrp2 (Fig. 2 C). Nrp2 is highly expressed in lymphatic capillaries and becomes internalized together with VEGFR-3 upon stimulation of LECs with VEGF-C and VEGF-D (Kärpänen et al., 2006a). Intriguingly, Nrp2 is important for capillary sprouting but dispensable for the formation of lymph sacs (Yuan et al., 2002; Xu et al., 2010). Vegfr-3 is initially expressed also in BECs but becomes mostly restricted to LECs after E10.5. Vegfr-3 signaling depends on interaction with claudinlike protein Clp24 and receptor internalization, a process requiring ephrin-B2 (Saharinen et al., 2010; Wang et al., 2010). Interestingly, the combined deletion of Vegfr-3 ligands Vegfc and Vegfd in mice does not phenocopy the inactivation of Vegfr3, pointing to a ligand-independent Vegfr-3 function (Haiko et al., 2008). Budding of LECs from veins requires Vegfr-3 kinase activity, whereas deletion of the Vegfr3 ligand-binding domain does not alter lymph sac formation (Fig. 2, A-C; Zhang et al., 2010). Proteolytically processed VEGF-C also interacts with VEGFR-2, which is expressed by lymphatic endothelium. However, activation of Vegfr-2 alone promotes lymphatic vessel enlargement but not sprouting (Wirzenius et al., 2007). VEGF-C induces formation of VEGFR-2/ VEGFR-3 heterodimers at angiogenic tip cells, suggesting that heterodimerization of VEGFR-3 with VEGFR-2 may contribute to lymphangiogenic sprouting (Nilsson et al., 2010). Endothelialspecific loss of Rho GTPase Rac1 leads to an abnormally close association of lymph sacs and cardinal veins, suggesting that it also regulates LEC budding from veins (D'Amico et al., 2009). Interestingly, postnatal development of lymphatic vessels in organs other than skin is Vegf-c/Vegfr-3 independent, and internal lymphatic capillaries regrow in mice with mutated Vegfr 3 or upon Vegf-c depletion (Karkkainen et al., 2001; Mäkinen et al., 2001; Kärpänen et al., 2006b).

In zebrafish, the secreted protein Ccbe 1 controls lymphatic sprouting from veins, and its function is conserved, as CCBE1 mutations cause human syndrome presenting with lymphatic dysplasia (Alders et al., 2009; Hogan et al., 2009a; see Heredity lymphedema syndromes). The venous origin of LECs and conserved function of VEGF-C, VEGFR-3, and CCBE1 (Karkkainen et al., 2000, 2003; Ny et al., 2005; Küchler et al., 2006; Yaniv et al., 2006; Alders et al., 2009; Hogan et al., 2009a,b) clearly underpin the common origin of the vertebrate lymphatic vasculature. Nevertheless, within this common scheme, there seem to be differences between mammalian and zebrafish LEC behavior: in mice, lymphatic sprouting occurs after veins have formed, whereas zebrafish venous sprouts and lymphatic precursors emerge from the cardinal vein simultaneously (Bussmann et al., 2010). Half of those venous sprouts connect with intersegmental vessels to form veins, whereas other sprouts disconnect from the vein and migrate toward the horizontal myoseptum region, constituting a pool of future LECs. These cells, called parachordal lymphangioblasts, migrate along arteries either dorsally to form intersegmental lymphatic vessels or ventrally to form the thoracic duct (Bussmann et al., 2010; Geudens et al., 2010). At $5 \mathrm{~d}$ after fertilization, a functional lymphatic system has been established in the zebrafish trunk capable of taking up substances from the interstitium and of transporting lymph into the venous system (Küchler et al., 2006; Yaniv et al., 2006). Future studies will have to show whether the requirement for arteries in guiding LEC migration is a zebrafish-specific feature or whether this represents a general scheme among vertebrates: the anatomical proximity of mammalian arteries and lymphatic vessels has often been noted but commonly attributed to high arterial pressure and a need of absorbing extravasated water and proteins near arteries. Using zebrafish, a role for Notch/D114 signaling has been demonstrated in guiding LECs along arteries (Geudens et al., 2010), and there might be earlier roles for Notch at the level of venous sprouting (Liao et al., 2010). Interestingly, loss of the arterial regulator synectin also compromises the development of zebrafish lymphatics (Hermans et al., 2010).

Hematopoietic cells and lymphatic vascular development. In mammals, lymphatic and blood vasculatures are connected only in a few defined locations where lymph is returned back to blood circulation. Platelets are important for keeping both vascular systems apart (Table I): platelet depletion or defective platelet aggregation leads to abnormal lymphovenous connections and blood-filled lymphatic vessels (Ichise et al., 2009; Bertozzi et al., 2010; Carramolino et al., 2010; SuzukiInoue et al., 2010; Uhrin et al., 2010). According to the current model, platelets aggregate at sites of communication between the cardinal vein and lymph sacs and "seal off" lymphatic vessels from the vein (Fig. 2, A and D). Platelet aggregation is initiated by binding of the O-glycosylated mucoprotein podoplanin expressed on LECs to the Clec-2 receptor on platelets (Bertozzi et al., 2010; Uhrin et al., 2010). Clec-2 further induces intracellular signaling 
cascades mediated by spleen tyrosine kinase (Syk), Slp76, and PLC- $\gamma 2$, which then lead to formation of the blood clot that seals off the vein from the lymph sac (Ichise et al., 2009; Bertozzi et al., 2010; Suzuki-Inoue et al., 2010).

In addition to platelets, myeloid cells regulate lymphatic vascular morphogenesis. Macrophage-deficient PU.1 $1^{-/-}$and Csfrl ${ }^{-/-}$ mice exhibit hyperplastic dermal lymphatic capillaries, suggesting that macrophages restrict proliferation of LECs (Gordon et al., 2010). Conversely, abnormal accumulation of myeloid cells, producing high levels of cytokines and VEGF-D, induces the formation of dermal lymphaticovenous shunts in $S y k^{-/-}$mice (Böhmer et al., 2010). Similar mechanisms are likely at play in Angptl4 ${ }^{-/-}$ mice, in which excessive macrophage activation by chylomicrons may be responsible for fusion of intestinal blood and lymphatic vessels (Bäckhed et al., 2007; Lichtenstein et al., 2010).

Lymphatic vascular remodeling and maturation. Starting from E15.5, the lymphatic vasculature is reorganized into lymphatic capillaries, precollectors, and collecting lymphatic vessels (Fig. 2 A). In mice, transient up-regulation of the forkhead transcription factor Foxc2 is the first sign of formation of collecting lymphatic vessels (Norrmén et al., 2009). Lymphatic valves continue to express high levels of Foxc2 and Prox1 throughout development and in adults. LECs in any given lymphangion decrease the expression of Prox1, Vegfr-3, LYVE-1, and Ccl21, secrete basement membrane components, and acquire SMC coverage (Mäkinen et al., 2005; Norrmén et al., 2009). In the absence of Foxc2, transition from capillary to collecting lymphatic vessel phenotype and formation of lymphatic valves are arrested (Petrova et al., 2004; Norrmén et al., 2009). FOXC2-bound enhancers in LECs are surrounded by nuclear factor of activated T cells (NFAT) binding sites, and pharmacological inhibition of NFAT activation results in lymphatic patterning defects reminiscent of Foxc $2^{-/-}$phenotypes (Norrmén et al., 2009). This suggests that Foxc2 and NFAT pathways cooperate in establishing collecting lymphatic vessels.

Ephrin-Eph signaling is essential for embryonic angiogenesis, and targeted inactivation in mice of ephrin-B2 or its receptor EphB4 leads to aberrant embryonic blood vessel formation (Adams and Eichmann, 2010). Reverse signaling via PDZ interaction sites of ephrin-B2 is also required for the maturation of collecting lymphatic vessels (Mäkinen et al., 2005). In mice, the presence of a mutation in this PDZ interaction site of ephrin-B2 prevents the formation of valves and leads to persistent LYVE-1 expression in presumptive collecting vessels. These mutant mice also display defective sprouting of lymphatic capillaries, which acquire ectopic SMC coverage (Mäkinen et al., 2005).

Integrin $\alpha 9$ and its ligand fibronectin (FN) containing the EIIIA domain (FN-EIIIA) control later steps of lymphatic valve formation (Bazigou et al., 2009). The integrin $\alpha 9-\beta 1$ complex binds to FN-EIIIA, tenascin, and osteopontin in vitro and regulates the organization of FN-EIIIA microfibrils. Loss of integrin $\alpha 9$ prevents the elongation of valve leaflets, resulting in the formation of ringlike constrictions, which are unable to prevent lymph backflow (Bazigou et al., 2009). Fn-EIIIA ${ }^{-/-}$mice have a similar phenotype, demonstrating that FN-EIIIA is a physiologically relevant integrin $\alpha 9$ ligand (Bazigou et al., 2009).

The Tie 1 and Tie 2 endothelial receptor tyrosine kinases are essential for blood vascular remodeling, maturation, and stabilization, and they also control lymphatic vascular development. Mice hypomorphic for Tie1 exhibit LEC hyperplasia and abnormal remodeling of lymph sacs, whereas mice deficient in one of the Tie2 ligands, angiopoietin-2, show defective lymphatic vascular remodeling and lack valves (Gale et al., 2002; Dellinger et al., 2008; D'Amico et al., 2010). Tie2 activation induces phosphoinositide (PI) 3-kinase and Akt signaling in vitro, and consistent with these observations, mutations in several PI3-kinase pathway components or loss of Akt1 leads to lymphatic-remodeling defects (Gupta et al., 2007; Mouta-Bellum et al., 2009; Zhou et al., 2010). Zebrafish tie $2^{-/-}$undergoes normal lymphangiogenesis. However, redundancy with Tie1 needs to be examined (Gjini et al., 2011).

\section{Pathological lymphatic vascular morphogenesis}

Given the importance of lymphatic vessels for normal body functions, it is not surprising that defects of the lymphatic vasculature are implicated in a variety of human pathologies. Roles of lymphatic vessels in tumor metastasis and inflammation have been recently covered in several excellent reviews (Sleeman et al., 2009; Tammela and Alitalo, 2010). Here, we will concentrate on the defects of vascular morphogenesis in human lymphedema syndromes and some rare but debilitating diseases in which lymphatic vasculature is suggested to play a central role.

Hereditary Iymphedema syndromes. Lymphatic vessel dysfunction results in progressive accumulation of proteinrich interstitial fluid and formation of nonpitting localized tissue swelling or lymphedema (Fig. 3). It is a chronic debilitating condition associated with increased local susceptibility to infections and certain cancers, such as angiosarcoma. Lymphedema can be inherited (primary lymphedema) but is more commonly caused by damage incurred by collecting lymphatic vessels or lymph nodes during cancer surgery or radiation therapy (secondary lymphedema). Pathologies of secondary lymphedema have recently been reviewed (Rockson, 2001, 2008; Tammela and Alitalo, 2010).

Hereditary lymphedema is a rare genetic disorder, which can develop in utero, neonatally, or more frequently, years or decades after birth (Fig. 3 and Table II). Missense mutations within the VEGFR-3 tyrosine kinase domain cause Milroy disease, which is characterized by underdeveloped and dysfunctioning cutaneous lymphatic vessels (Karkkainen et al., 2000; Mellor et al., 2010). Recently, mutations in the recessive $C C B E 1$ gene, shown to control lymphatic sprouting in zebrafish (Hogan et al., 2009a), have been identified in a subset of Hennekam syndrome patients, who develop limb lymphedema, dilated intestinal lymphatic vessels, mental retardation, and facial anomalies (Alders et al., 2009). Intestinal lymphatic capillaries are also reduced in number and abnormally patterned, suggesting that defective lymphatic capillary function is a cause of the syndrome (Alders et al., 2009).

Loss-of-function mutations in FOXC2 cause lymphedemadistichiasis syndrome (LD), which is characterized by late onset lymphedema and a double row of eyelashes (distichiasis; Fang et al., 2000). Gain-of-function mutations in FOXC2 occur in patients with lymphedema, but the association of these mutations with distichiasis awaits further investigation (van Steensel 
Figure 3. Causes of human hereditary lymphedemas. Lymph transport can be impaired because of a hypoplastic initial lymphatic capillary network, because of abnormal coverage of lymphatic capillaries with basement membrane components and SMCs or because of a lack of or malfunctioning lymphatic valves. Defective lymphatic drainage leads to tissue fibrosis and fat deposition caused by the abnormal local chronic inflammatory response. Genes that are mutated in human hereditary lymphedema are indicated in blue next to the processes to which they are thought to be causally related. Mechanisms of the action of GJC2, PTPN14, and IKBKG are not fully understood.
Normal lymphatic vasculature

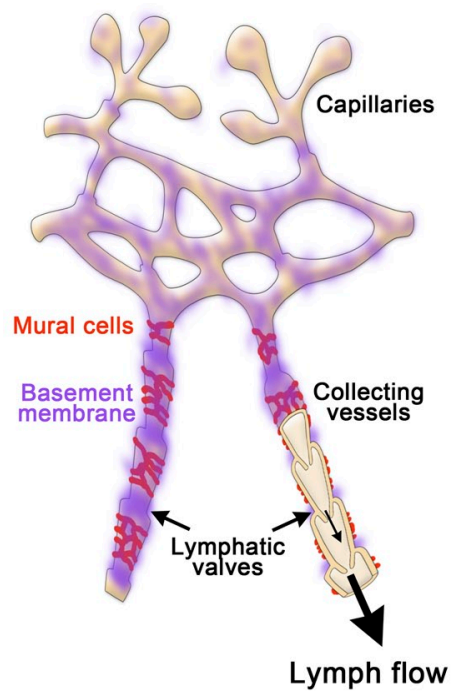

Lymphedema-associated lymphatic vasculature
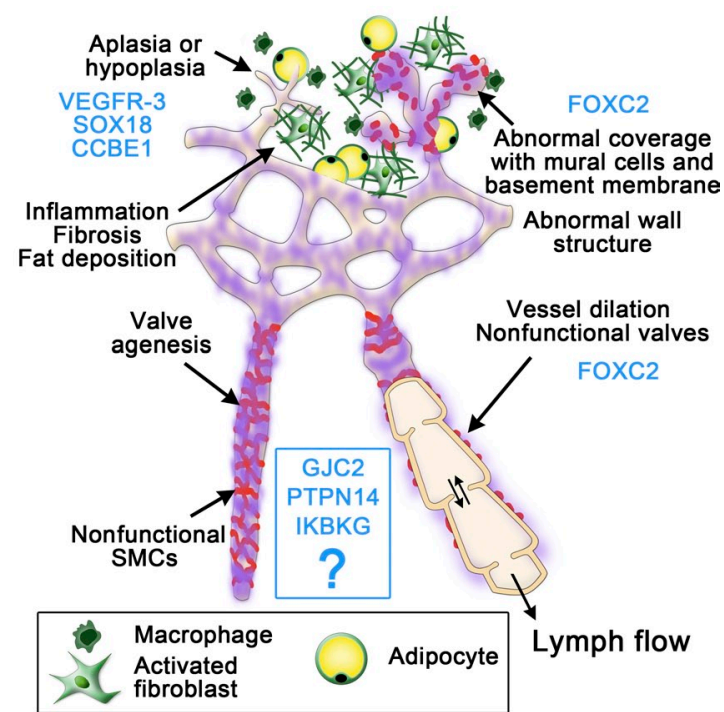

et al., 2009). Lymphatic vessel density is normal or increased in LD patients; however, lymphatic transport is inefficient because of lymph reflux, likely caused by incompetent lymphatic valves. LD patients also have venous reflux, suggesting a common mechanism for the morphogenesis of venous and lymphatic valves (Brice et al., 2002; Mellor et al., 2007)

Dominant-negative mutations in SOX18 occur in hypotrichosis-lymphedema-telangiectasia syndrome (HLT) characterized by sparse hair, swelling of legs, and dilation of small blood vessels. Based on phenotypic similarities with mice producing a dominant-negative form of Sox18, HLT patients likely have lymphatic capillary hypoplasia (Irrthum et al., 2003; François et al., 2008). Novel causes of hereditary lymphedema include mutations in gap junction protein GJC2 and protein tyrosine phosphatase PTPN14 (Au et al., 2010; Ferrell et al., 2010). GJC2 is highly expressed by oligodendrocytes, and recessive loss-of-function mutations in GJC2 cause hereditary Pelizaeus-Merzbacher-like disease, which is characterized by central nervous system demyelination. Given the dominant character of GJC2 mutations in lymphedema, mutant proteins might exert a dominant-negative effect either on remaining wild-type GJC2 molecules or other connexins. A subset of Ptpn14-deficient mice has hyperplastic lymphatic vasculature, and a role for PTPN14 in restricting Vegfr-3 activation has been proposed (Au et al., 2010).

Lymphangioleiomyomatosis (LAMJ. LAM is a rare lung disease affecting women of childbearing age characterized by the proliferation of smooth muscle-like cells and lymphatic vessels as well as the formation of pulmonary cysts. LAM can also occur in the axial lymphatics and is associated with a benign kidney tumor angiomyolipoma (Seyama et al., 2010). The origin of the SMCs in LAM lesions is unknown, but they respond to estrogen and express multiple chemokine receptors and lymphangiogenic growth factors VEGF-C and VEGF-D, which may explain the highly metastatic behavior of LAM cells and their close association with lymphatic vessels (Pacheco-Rodriguez et al., 2009; Yu et al., 2009). LAM is a benign neoplasm. However, LAM cells frequently disseminate through lymphatic vessels to distant sites, where they may block lymphatic function, causing accumulation of lymph in the chest and abdominal cavity and lymphedema. The cystic destruction of the lung parenchyma over time impairs lung function, which is ultimately only rescuable through lung transplantation (Seyama et al., 2010).

The kinase mammalian target of rapamycin (mTOR) plays a central role in integrating growth factor-activated signaling. Its abnormal activation is a likely cause of LAM, as patients with germline mutations of mTOR repressors tuberosis sclerosis complex-1 and -2 (TSC1 and TSC2) genes develop the disease. Somatic biallelic loss of TSC2 occurs in sporadic LAM cases (Carsillo et al., 2000; Sato et al., 2002). In line with these findings, encouraging results were observed in patients treated with mTOR inhibitors (Glasgow et al., 2010). Given the close association of LAM cells with lymphatic vessels and the lymphatic pattern of dissemination, combining the blockage of mTOR with antilymphangiogenic therapy seems to be a reasonable further step in developing better treatment for this disease.

Gorham disease (GD). GD is a rare disease of unknown etiology characterized by bone resorption and local vascular proliferation. The disease is frequently complicated by systemic dysfunction of lymphatic vessels, such as chylothorax and chylous ascites (Radhakrishnan and Rockson, 2008). Endothelial cells in the lesions are likely of LEC origin, as they express LEC markers LYVE-1 and podoplanin, and VEGFR-3 is increased in $50 \%$ of vessels (Hagendoorn et al., 2006). Nonendothelial cells from GD lesions resemble immature osteoclasts; they secrete cytokines and angiogenic factors, are highly invasive, and may, thus, contribute to disease progression (Colucci et al., 2006). Moreover, GD osteoclast precursors show increased sensitivity to humoral factors, promoting osteoclast formation and bone resorption (Hirayama et al., 2001). Overall, the clinical picture points to an intriguing link between LEC proliferation and activation of osteoclast-mediated bone resorption; however, at present, no candidate genes for GD have been identified.

Kaposi sarcoma (KS): a case of mixed identity. $\mathrm{KS}$ is a tumor caused by human herpes virus 8 (HHV8 or 
Table II. Main human hereditary lymphedema syndromes

\begin{tabular}{|c|c|c|c|c|c|}
\hline Name & Inheritance & MIM number & Main manifestations & Mutated gene & Candidate locus \\
\hline \multicolumn{6}{|c|}{ Syndromes with lymphedema as a primary manifestation } \\
\hline $\begin{array}{l}\text { Hereditary lymphedema IA } \\
\text { (Milroy disease) }\end{array}$ & $\begin{array}{l}\text { Autosomal dominant } \\
\text { with reduced } \\
\text { penetrance }\end{array}$ & 153100 & $\begin{array}{l}\text { Congenital lymphedema, chylous } \\
\text { ascites caused by hypoplasia of } \\
\text { lymphatic vessels }\end{array}$ & FLT4 (VEGFR-3) & $5 q 35.3$ \\
\hline Hereditary lymphedema IB & $\begin{array}{l}\text { Autosomal dominant } \\
\text { with reduced } \\
\text { penetrance }\end{array}$ & 611944 & $\begin{array}{l}\text { Lymphedema of lower limbs, nature } \\
\text { of lymphatic vascular defects is } \\
\text { unknown }\end{array}$ & Unknown & $6 q 16.2-q 22.1$ \\
\hline Hereditary lymphedema IC & Autosomal dominant & 613480 & $\begin{array}{l}\text { Lymphedema of limbs, age of onset } \\
1-15 \mathrm{yr} \text {, nature of lymphatic } \\
\text { vascular defects is unknown }\end{array}$ & GJC2 (connexin47) & $1 q 41-q 42$ \\
\hline $\begin{array}{l}\text { Hereditary lymphedema II } \\
\text { (Meige disease) }\end{array}$ & Unknown & 153200 & $\begin{array}{l}\text { Puberty onset lymphedema, nature } \\
\text { of lymphatic vascular defects is } \\
\text { unknown }\end{array}$ & Unknown & Unknown \\
\hline \multicolumn{6}{|c|}{ Syndromes with lymphedema as a consistent feature } \\
\hline $\begin{array}{l}\text { Anhidrotic ectodermal dysplasia } \\
\text { with immunodeficiency, } \\
\text { osteopetrosis and lymphedema }\end{array}$ & X-linked recessive & 300301 & $\begin{array}{l}\text { Severe infections, osteopetrosis, } \\
\text { nature of lymphatic vascular } \\
\text { defects is unknown }\end{array}$ & $\begin{array}{l}\text { IKBKG (Nemo) } \\
\text { TER42OTRP }\end{array}$ & $\mathrm{Xq} 28$ \\
\hline $\begin{array}{l}\text { Cholestasis-lymphedema } \\
\text { syndrome (Aagenaes syndrome) }\end{array}$ & Autosomal recessive & 214900 & $\begin{array}{l}\text { Severe neonatal cholestasis, neonatal } \\
\text { or childhood onset lymphedema } \\
\text { caused by hypoplasia of lymphatic } \\
\text { vessels }\end{array}$ & Unknown & $15 q 1$ \\
\hline $\begin{array}{l}\text { Hennekam lymphangiectasia- } \\
\text { lymphedema syndrome }\end{array}$ & Autosomal recessive & 235510 & $\begin{array}{l}\text { Lymphedema of limbs, intestinal } \\
\text { lymphangiectasia, mental } \\
\text { retardation, facial anomalies }\end{array}$ & CCBE 1 & $18 q 21.32$ \\
\hline HLT syndrome & Autosomal dominant & 607823 & $\begin{array}{l}\text { Alopecia, ectatic blood vessels, } \\
\text { lymphedema, nature of lymphatic } \\
\text { vascular defects is unknown }\end{array}$ & SOX18 & $20 q 13.33$ \\
\hline $\begin{array}{l}\text { Lymphedema, microcephaly, } \\
\text { chorioretinopathy syndrome }\end{array}$ & Autosomal dominant & 152950 & $\begin{array}{l}\text { Congenital microcephaly and } \\
\text { lymphedema, nature of lymphatic } \\
\text { vascular defects is unknown }\end{array}$ & Unknown & Unknown \\
\hline $\begin{array}{l}\text { Lymphedema-choanal atresia } \\
\text { syndrome }\end{array}$ & Autosomal recessive & 608911 & $\begin{array}{l}\text { Blockage of nasal passage (choana), } \\
\text { lymphedema of lower legs at } \\
4-5 \mathrm{yr} \text {, nature of lymphatic } \\
\text { vascular defects is unknown }\end{array}$ & PTPN14 & $1 q 32-q 41$ \\
\hline $\begin{array}{l}\text { Lymphedema-distichiasis syn- } \\
\text { drome, yellow nail syndrome }\end{array}$ & Autosomal dominant & $\begin{array}{c}153400 / \\
153300\end{array}$ & $\begin{array}{l}\text { Late onset leg lymphedema and } \\
\text { metaplasia of Meibomian glands } \\
\text { (distichiasis), impaired lymphatic } \\
\text { drainage caused by incompetent } \\
\text { lymphatic valves }\end{array}$ & FOXC2 & $6 q 24.3$ \\
\hline $\begin{array}{l}\text { Persistence of mullerian deriva- } \\
\text { tives with lymphangiectasia and } \\
\text { postaxial polydactyly (Urioste } \\
\text { syndrome) }\end{array}$ & Autosomal recessive? & 235255 & $\begin{array}{l}\text { Intestinal and pulmonary } \\
\text { lymphangiectasia, protein-losing } \\
\text { entheropathy, polydactyly, and } \\
\text { mullerian duct remnants }\end{array}$ & Unknown & Unknown \\
\hline $\begin{array}{l}\text { Pulmonary congenital lymphan- } \\
\text { giectasia }\end{array}$ & Unknown & 265300 & $\begin{array}{l}\text { Congenital pulmonary lymphangiecta- } \\
\text { sia, subcutaneous edema, } \\
\text { nonimmune hydrops, chylothorax }\end{array}$ & Unknown & Unknown \\
\hline
\end{tabular}

References can be found under the corresponding Online Mendelian Inheritance of Man (MIM) entry.

KS-associated herpes virus [KSHV]). The lesions are composed of spindle-shaped tumor cells, leaky and highly proliferative vessels, extravasated red blood cells, and inflammatory infiltrate (Mesri et al., 2010). KS cells express markers of both blood (CD34 and CXCR4) and LEC lineages (VEGFR-3, LYVE-1, and podoplanin). Interestingly, KSHV infection of BECs shifts the transcriptional profile toward a LEC phenotype, whereas KSHV infection of LECs induces transcriptional reprogramming toward a more BEC-like phenotype (Hong et al., 2004; Wang et al., 2004).

The major latency viral transcripts expressed in KS cells include the latency-associated nuclear antigen, viral cyclin, vFLIP, viral-encoded micro-RNAs, and kaposin-A and -B. These transcripts are important for KHSV-induced cell proliferation, production of proangiogenic and inflammatory cytokines, and unrestricted replicative potential (Mesri et al., 2010). Notably, some of these molecules control endothelial cell differentiation in vitro: four KS micro-RNAs target the transcription factor MAF and contribute to reprogramming of the LEC to BEC phenotype, whereas kaposin-B stabilizes PROX1 mRNA, which has a key role in lymphatic endothelial identity (Hansen et al., 2010; Yoo et al., 2010). Overall, these data provide an intriguing example of virusmediated change of the endothelial cell differentiation program.

Open questions and outlook

Impressive progress has been achieved in the past decade in the field of lymphatic vascular biology, but many questions remain 
unresolved. Development of novel imaging techniques and analysis of signaling pathways in situ will certainly provide additional insights into the mechanisms of lymphangiogenesis. Considerable phenotypic plasticity of endothelial cells is now obvious; however, the genetic and epigenetic mechanisms of LEC differentiation are far from being fully understood. Contributions of other cell types in regulating lymphatic development and function need to be addressed under physiological and pathological conditions. Finally, organ- and disease-specific features and responses of lymphatic endothelium have not been studied in detail, although this knowledge may have a critical impact on developing better treatments for human pathologies, including lymphedema, cancer, and inflammation.

We thank Caroline Heckman and Jeremiah Bernier-Latmani for discussions, and we apologize to colleagues whose work could not be cited because of space limitations.

The authors' work is supported by the Swiss National Science Foundation (grant PPPO033-1 14898), the Medic, Telethon, and Emma Muschamp Foundations, the National Center of Competence in Research Molecular Oncology, the Oncosuisse, the Swiss Cancer League, the Association for International Cancer Research, the Royal Netherlands Academy of Arts and Sciences, and the Wageningen University and Research Centre.

Submitted: 15 December 2010

Accepted: 11 April 2011

\section{References}

Abtahian, F., A. Guerriero, E. Sebzda, M.M. Lu, R. Zhou, A. Mocsai, E.E. Myers, B. Huang, D.G. Jackson, V.A. Ferrari, et al. 2003. Regulation of blood and lymphatic vascular separation by signaling proteins SLP-76 and Syk. Science. 299:247-251. doi:10.1126/science.1079477

Adams, R.H., and A. Eichmann. 2010. Axon guidance molecules in vascular patterning. Cold Spring Harb. Perspect. Biol. 2:a001875. doi:10.1101/cshperspect.a001875

Alders, M., B.M. Hogan, E. Gjini, F. Salehi, L. Al-Gazali, E.A. Hennekam, E.E. Holmberg, M.M. Mannens, M.F. Mulder, G.J. Offerhaus, et al. 2009. Mutations in CCBE1 cause generalized lymph vessel dysplasia in humans. Nat. Genet. 41:1272-1274. doi:10.1038/ng.484

Au, A.C., P.A. Hernandez, E. Lieber, A.M. Nadroo, Y.M. Shen, K.A. Kelley, B.D. Gelb, and G.A. Diaz. 2010. Protein tyrosine phosphatase PTPN14 is a regulator of lymphatic function and choanal development in humans. Am. J. Hum. Genet. 87:436-444. doi:10.1016/j.ajhg.2010.08.008

Ayadi, A., H. Zheng, P. Sobieszczuk, G. Buchwalter, P. Moerman, K. Alitalo, and B. Wasylyk. 2001. Net-targeted mutant mice develop a vascular phenotype and up-regulate egr-1. EMBO J. 20:5139-5152. doi:10.1093/ emboj/20.18.5139

Bäckhed, F., P.A. Crawford, D. O'Donnell, and J.I. Gordon. 2007. Postnatal lymphatic partitioning from the blood vasculature in the small intestine requires fasting-induced adipose factor. Proc. Natl. Acad. Sci. USA. 104:606-611. doi:10.1073/pnas.0605957104

Baluk, P., J. Fuxe, H. Hashizume, T. Romano, E. Lashnits, S. Butz, D. Vestweber, M. Corada, C. Molendini, E. Dejana, and D.M. McDonald. 2007. Functionally specialized junctions between endothelial cells of lymphatic vessels. J. Exp. Med. 204:2349-2362. doi:10.1084/jem.20062596

Bazigou, E., S. Xie, C. Chen, A. Weston, N. Miura, L. Sorokin, R. Adams, A.F. Muro, D. Sheppard, and T. Makinen. 2009. Integrin-alpha9 is required for fibronectin matrix assembly during lymphatic valve morphogenesis. Dev. Cell. 17:175-186. doi:10.1016/j.devcel.2009.06.017

Bertozzi, C.C., A.A. Schmaier, P. Mericko, P.R. Hess, Z. Zou, M. Chen, C.Y. Chen, B. Xu, M.M. Lu, D. Zhou, et al. 2010. Platelets regulate lymphatic vascular development through CLEC-2-SLP-76 signaling. Blood. 116:661-670. doi:10.1182/blood-2010-02-270876

Böhmer, R., B. Neuhaus, S. Bühren, D. Zhang, M. Stehling, B. Böck, and F. Kiefer. 2010. Regulation of developmental lymphangiogenesis by Syk(+) leukocytes. Dev. Cell. 18:437-449. doi:10.1016/j.devcel.2010.01.009

Brice, G., S. Mansour, R. Bell, J.R. Collin, A.H. Child, A.F. Brady, M. Sarfarazi, K.G. Burnand, S. Jeffery, P. Mortimer, and V.A. Murday. 2002. Analysis of the phenotypic abnormalities in lymphoedema-distichiasis syndrome in 74 patients with FOXC2 mutations or linkage to 16q24. J. Med. Genet. 39:478-483. doi:10.1136/jmg.39.7.478
Bussmann, J., F.L. Bos, A. Urasaki, K. Kawakami, H.J. Duckers, and S. SchulteMerker. 2010. Arteries provide essential guidance cues for lymphatic endothelial cells in the zebrafish trunk. Development. 137:2653-2657. doi:10.1242/dev.048207

Carramolino, L., J. Fuentes, C. García-Andrés, V. Azcoitia, D. Riethmacher, and M. Torres. 2010. Platelets play an essential role in separating the blood and lymphatic vasculatures during embryonic angiogenesis. Circ. Res. 106:1197-1201. doi:10.1161/CIRCRESAHA.110.218073

Carsillo, T., A. Astrinidis, and E.P. Henske. 2000. Mutations in the tuberous sclerosis complex gene TSC2 are a cause of sporadic pulmonary lymphangioleiomyomatosis. Proc. Natl. Acad. Sci. USA. 97:6085-6090. doi:10 $.1073 /$ pnas.97.11.6085

Chen, L., A. Mupo, T. Huynh, S. Cioffi, M. Woods, C. Jin, W. McKeehan, L. Thompson-Snipes, A. Baldini, and E. Illingworth. 2010. Tbx1 regulates Vegfr 3 and is required for lymphatic vessel development. J. Cell Biol. 189:417-424. doi:10.1083/jcb.200912037

Colucci, S., G. Taraboletti, L. Primo, A. Viale, C. Roca, D. Valdembri, M. Geuna, M. Pagano, M. Grano, A.M. Pogrel, et al. 2006. Gorham-Stout syndrome: a monocyte-mediated cytokine propelled disease. J. Bone Miner. Res. 21:207-218. doi:10.1359/JBMR.051019

Dagenais, S.L., R.L. Hartsough, R.P. Erickson, M.H. Witte, M.G. Butler, and T.W. Glover. 2004. Foxc2 is expressed in developing lymphatic vessels and other tissues associated with lymphedema-distichiasis syndrome. Gene Expr. Patterns. 4:611-619. doi:10.1016/j.modgep.2004.07.004

D’Amico, G., D.T. Jones, E. Nye, K. Sapienza, A.R. Ramjuan, L.E. Reynolds, S.D. Robinson, V. Kostourou, D. Martinez, D. Aubyn, et al. 2009. Regulation of lymphatic-blood vessel separation by endothelial Rac1. Development. 136:4043-4053. doi:10.1242/dev.035014

D’Amico, G., E.A. Korhonen, M. Waltari, P. Saharinen, P. Laakkonen, and K. Alitalo. 2010. Loss of endothelial Tiel receptor impairs lymphatic vessel development-brief report. Arterioscler. Thromb. Vasc. Biol. 30:207-209. doi:10.1161/ATVBAHA.109.196618

Danussi, C., P. Spessotto, A. Petrucco, B. Wassermann, P. Sabatelli, M. Montesi, R. Doliana, G.M. Bressan, and A. Colombatti. 2008. Emilin1 deficiency causes structural and functional defects of lymphatic vasculature. $\mathrm{Mol}$. Cell. Biol. 28:4026-4039. doi:10.1128/MCB.02062-07

Dejana, E., F. Orsenigo, C. Molendini, P. Baluk, and D.M. McDonald. 2009. Organization and signaling of endothelial cell-to-cell junctions in various regions of the blood and lymphatic vascular trees. Cell Tissue Res. 335:17-25. doi:10.1007/s00441-008-0694-5

Dellinger, M., R. Hunter, M. Bernas, N. Gale, G. Yancopoulos, R. Erickson, and M. Witte. 2008. Defective remodeling and maturation of the lymphatic vasculature in Angiopoietin-2 deficient mice. Dev. Biol. 319:309-320. doi:10.1016/j.ydbio.2008.04.024

Fang, J., S.L. Dagenais, R.P. Erickson, M.F. Arlt, M.W. Glynn, J.L. Gorski, L.H. Seaver, and T.W. Glover. 2000. Mutations in FOXC2 (MFH-1), a forkhead family transcription factor, are responsible for the hereditary lymphedema-distichiasis syndrome. Am. J. Hum. Genet. 67:1382-1388. doi:10.1086/316915

Ferrell, R.E., C.J. Baty, M.A. Kimak, J.M. Karlsson, E.C. Lawrence, M. FrankeSnyder, S.D. Meriney, E. Feingold, and D.N. Finegold. 2010. GJC2 missense mutations cause human lymphedema. Am. J. Hum. Genet. 86:943-948. doi:10.1016/j.ajhg.2010.04.010

Földi, M., E. Földi, R.H.K. Strößenreuther, and S. Kubic, editors. 2006. Földi’s Textbook of Lymphology: For Physicians and Lymphedema Therapists. Second edition. Urban and Fischer, Munich. 736 pp.

François, M., A. Caprini, B. Hosking, F. Orsenigo, D. Wilhelm, C. Browne, K. Paavonen, T. Karnezis, R. Shayan, M. Downes, et al. 2008. Sox 18 induces development of the lymphatic vasculature in mice. Nature. 456:643-647. doi:10.1038/nature07391

Fritz-Six, K.L., W.P. Dunworth, M. Li, and K.M. Caron. 2008. Adrenomedullin signaling is necessary for murine lymphatic vascular development. J. Clin. Invest. 118:40-50. doi:10.1172/JCI33302

Fu, J., H. Gerhardt, J.M. McDaniel, B. Xia, X. Liu, L. Ivanciu, A. Ny, K. Hermans, R. Silasi-Mansat, S. McGee, et al. 2008. Endothelial cell O-glycan deficiency causes blood/lymphatic misconnections and consequent fatty liver disease in mice. J. Clin. Invest. 118:3725-3737. doi:10.1172/JCI36077

Gale, N.W., G. Thurston, S.F. Hackett, R. Renard, Q. Wang, J. McClain, C. Martin, C. Witte, M.H. Witte, D. Jackson, et al. 2002. Angiopoietin-2 is required for postnatal angiogenesis and lymphatic patterning, and only the latter role is rescued by Angiopoietin-1. Dev. Cell. 3:411-423. doi:10.1016/S1534-5807(02)00217-4

Geudens, I., R. Herpers, K. Hermans, I. Segura, C. Ruiz de Almodovar, J. Bussmann, F. De Smet, W. Vandevelde, B.M. Hogan, A. Siekmann, et al. 2010. Role of delta-like-4/Notch in the formation and wiring of the lymphatic network in zebrafish. Arterioscler. Thromb. Vasc. Biol. 30:16951702. doi:10.1161/ATVBAHA.110.203034 
Gjini, E., L.H. Hekking, A. Küchler, P. Saharinen, E. Wienholds, J.A. Post, K. Alitalo, and S. Schulte-Merker. 2011. Zebrafish Tie-2 shares a redundant role with Tie-1 in heart development and regulates vessel integrity. Dis Model Mech. 4:57-66. doi:10.1242/dmm.005033

Glasgow, C.G., W.K. Steagall, A. Taveira-Dasilva, G. Pacheco-Rodriguez, X. Cai, S. El-Chemaly, M. Moses, T. Darling, and J. Moss. 2010. Lymphangioleiomyomatosis (LAM): molecular insights lead to targeted therapies. Respir. Med. 104(Suppl. 1):S45-S58. doi:10.1016/j.rmed .2010.03.017

Gordon, E.J., S. Rao, J.W. Pollard, S.L. Nutt, R.A. Lang, and N.L. Harvey. 2010 Macrophages define dermal lymphatic vessel calibre during development by regulating lymphatic endothelial cell proliferation. Development. 137:3899-3910. doi:10.1242/dev.050021

Gupta, S., A.R. Ramjaun, P. Haiko, Y. Wang, P.H. Warne, B. Nicke, E. Nye, G. Stamp, K. Alitalo, and J. Downward. 2007. Binding of ras to phosphoinositide 3-kinase p110alpha is required for ras-driven tumorigenesis in mice. Cell. 129:957-968. doi:10.1016/j.cell.2007.03.051

Hagendoorn, J., T.P. Padera, T.I. Yock, G.P. Nielsen, E. di Tomaso, D.G. Duda, T.F. Delaney, H.A. Gaissert, J. Pearce, A.E. Rosenberg, et al. 2006. Platelet-derived growth factor receptor-beta in Gorham's disease. Nat Clin. Pract. Oncol. 3:693-697. doi:10.1038/ncponc0660

Haiko, P., T. Makinen, S. Keskitalo, J. Taipale, M.J. Karkkainen, M.E. Baldwin, S.A. Stacker, M.G. Achen, and K. Alitalo. 2008. Deletion of vascular endothelial growth factor C (VEGF-C) and VEGF-D is not equivalent to VEGF receptor 3 deletion in mouse embryos. Mol. Cell. Biol. 28:48434850. doi:10.1128/MCB.02214-07

Hansen, A., S. Henderson, D. Lagos, L. Nikitenko, E. Coulter, S. Roberts, F. Gratrix, K. Plaisance, R. Renne, M. Bower, et al. 2010. KSHV-encoded miRNAs target MAF to induce endothelial cell reprogramming. Genes Dev. 24:195-205. doi:10.1101/gad.553410

Harvey, N.L., R.S. Srinivasan, M.E. Dillard, N.C. Johnson, M.H. Witte, K. Boyd, M.W. Sleeman, and G. Oliver. 2005. Lymphatic vascular defects promoted by Prox 1 haploinsufficiency cause adult-onset obesity. Nat. Genet. 37:1072-1081. doi:10.1038/ng1642

Hermans, K., F. Claes, W. Vandevelde, W. Zheng, I. Geudens, F. Orsenigo, F De Smet, E. Gjini, K. Anthonis, B. Ren, et al. 2010. Role of synectin in lymphatic development in zebrafish and frogs. Blood. 116:3356-3366. doi:10.1182/blood-2009-11-254557

Hirashima, M., K. Sano, T. Morisada, K. Murakami, J. Rossant, and T. Suda 2008. Lymphatic vessel assembly is impaired in Aspp1-deficient mouse embryos. Dev. Biol. 316:149-159. doi:10.1016/j.ydbio.2008.01.023

Hirayama, T., A. Sabokbar, I. Itonaga, S. Watt-Smith, and N.A. Athanasou 2001. Cellular and humoral mechanisms of osteoclast formation and bone resorption in Gorham-Stout disease. J. Pathol. 195:624-630. doi:10 $.1002 /$ path.989

Hogan, B.M., F.L. Bos, J. Bussmann, M. Witte, N.C. Chi, H.J. Duckers, and S. Schulte-Merker. 2009a. Ccbe1 is required for embryonic lymphangiogenesis and venous sprouting. Nat. Genet. 41:396-398. doi:10 $.1038 /$ ng.321

Hogan, B.M., R. Herpers, M. Witte, H. Heloterä, K. Alitalo, H.J. Duckers, and S. Schulte-Merker. 2009b. Vegfc/Flt4 signalling is suppressed by D114 in developing zebrafish intersegmental arteries. Development. 136:40014009. doi:10.1242/dev.039990

Hong, Y.K., N. Harvey, Y.H. Noh, V. Schacht, S. Hirakawa, M. Detmar, and G. Oliver. 2002. Prox 1 is a master control gene in the program specifying lymphatic endothelial cell fate. Dev. Dyn. 225:351-357. doi:10 $.1002 /$ dvdy. 10163

Hong, Y.K., K. Foreman, J.W. Shin, S. Hirakawa, C.L. Curry, D.R. Sage, T. Libermann, B.J. Dezube, J.D. Fingeroth, and M. Detmar. 2004. Lymphatic reprogramming of blood vascular endothelium by Kaposi sarcoma-associated herpesvirus. Nat. Genet. 36:683-685. doi:10.1038/ ng1383

Ichise, H., T. Ichise, O. Ohtani, and N. Yoshida. 2009. Phospholipase Cgamma2 is necessary for separation of blood and lymphatic vasculature in mice. Development. 136:191-195. doi:10.1242/dev.025353

Irrthum, A., K. Devriendt, D. Chitayat, G. Matthijs, C. Glade, P.M. Steijlen, J.P. Fryns, M.A. Van Steensel, and M. Vikkula. 2003. Mutations in the transcription factor gene SOX18 underlie recessive and dominant forms of hypotrichosis-lymphedema-telangiectasia. Am. J. Hum. Genet. 72:14701478. doi:10.1086/375614

Johnson, N.C., M.E. Dillard, P. Baluk, D.M. McDonald, N.L. Harvey, S.L. Frase, and G. Oliver. 2008. Lymphatic endothelial cell identity is reversible and its maintenance requires Prox1 activity. Genes Dev. 22:3282-3291. doi:10.1101/gad.1727208

Kaipainen, A., J. Korhonen, T. Mustonen, V.W. van Hinsbergh, G.-H. Fang, D. Dumont, M. Breitman, and K. Alitalo. 1995. Expression of the fms-like tyrosine kinase 4 gene becomes restricted to lymphatic endothelium during development. Proc. Natl. Acad. Sci. USA. 92:3566-3570. doi:10 $.1073 /$ pnas.92.8.3566
Kampmeier, O.F. 1969. Evolution and Comparative Morphology of the Lymphatic System. Charles C. Thomas, Springfield, IL. 620 pp.

Karkkainen, M.J., R.E. Ferrell, E.C. Lawrence, M.A. Kimak, K.L. Levinson, M.A. McTigue, K. Alitalo, and D.N. Finegold. 2000. Missense mutations interfere with VEGFR-3 signalling in primary lymphoedema. Nat. Genet. 25:153-159. doi:10.1038/75997

Karkkainen, M.J., A. Saaristo, L. Jussila, K.A. Karila, E.C. Lawrence, K. Pajusola, H. Bueler, A. Eichmann, R. Kauppinen, M.I. Kettunen, et al. 2001. A model for gene therapy of human hereditary lymphedema. Proc. Natl. Acad. Sci. USA. 98:12677-12682. doi:10.1073/pnas.221449198

Karkkainen, M.J., P. Haiko, K. Sainio, J. Partanen, J. Taipale, T.V. Petrova, M. Jeltsch, D.G. Jackson, M. Talikka, H. Rauvala, et al. 2003. Vascular endothelial growth factor $\mathrm{C}$ is required for sprouting of the first lymphatic vessels from embryonic veins. Nat. Immunol. 5:74-80. doi:10 .1038/ni1013

Kärpänen, T., C.A. Heckman, S. Keskitalo, M. Jeltsch, H. Ollila, G. Neufeld, L. Tamagnone, and K. Alitalo. 2006a. Functional interaction of VEGF-C and VEGF-D with neuropilin receptors. FASEB J. 20:1462-1472. doi:10 1096/fj.05-5646com

Kärpänen, T., M. Wirzenius, T. Mäkinen, T. Veikkola, H.J. Haisma, M.G. Achen, S.A. Stacker, B. Pytowski, S. Ylä-Herttuala, and K. Alitalo. 2006b. Lymphangiogenic growth factor responsiveness is modulated by postnatal lymphatic vessel maturation. Am. J. Pathol. 169:708-718. doi:10 .2353/ajpath.2006.051200

Küchler, A.M., E. Gjini, J. Peterson-Maduro, B. Cancilla, H. Wolburg, and S. Schulte-Merker. 2006. Development of the zebrafish lymphatic system requires VEGFC signaling. Curr. Biol. 16:1244-1248. doi:10.1016/ j.cub.2006.05.026

Kuhnert, F., L. Campagnolo, J.W. Xiong, D. Lemons, M.J. Fitch, Z. Zou, W.B. Kiosses, H. Gardner, and H. Stuhlmann. 2005. Dosage-dependent requirement for mouse Vezf1 in vascular system development. Dev. Biol. 283:140-156. doi:10.1016/j.ydbio.2005.04.003

Lauweryns, J.M., and L. Boussauw. 1973. The ultrastructure of lymphatic valves in the adult rabbit lung. Z. Zellforsch. Mikrosk. Anat. 143:149-168. doi:10.1007/BF00307476

Leak, L.V., and J.F. Burke. 1968. Ultrastructural studies on the lymphatic anchoring filaments. J. Cell Biol. 36:129-149. doi:10.1083/jcb.36.1.129

Lee, S., J. Kang, J. Yoo, S.K. Ganesan, S.C. Cook, B. Aguilar, S. Ramu, J. Lee, and Y.K. Hong. 2009. Prox 1 physically and functionally interacts with COUP-TFII to specify lymphatic endothelial cell fate. Blood. 113:18561859. doi:10.1182/blood-2008-03-145789

Liao, S., T.P. Padera, and R.K. Jain. 2010. Notch leads lymphatics and links them to blood vessels. Arterioscler. Thromb. Vasc. Biol. 30:1682-1683. doi:10.1161/ATVBAHA.110.210633

Lichtenstein, L., F. Mattijssen, N.J. de Wit, A. Georgiadi, G.J. Hooiveld, R. van der Meer, Y. He, L. Qi, A. Köster, J.T. Tamsma, et al. 2010. Angptl4 protects against severe proinflammatory effects of saturated fat by inhibiting fatty acid uptake into mesenteric lymph node macrophages. Cell Metab. 12:580-592. doi:10.1016/j.cmet.2010.11.002

Lin, F.J., X. Chen, J. Qin, Y.K. Hong, M.J. Tsai, and S.Y. Tsai. 2010. Direct transcriptional regulation of neuropilin-2 by COUP-TFII modulates multiple steps in murine lymphatic vessel development. J. Clin. Invest. 120:1694 1707. doi:10.1172/JCI40101

Mäkinen, T., L. Jussila, T. Veikkola, T. Kärpänen, M.I. Kettunen, K.J. Pulkkanen, R. Kauppinen, D.G. Jackson, H. Kubo, S.-I. Nishikawa, et al. 2001. Inhibition of lymphangiogenesis with resulting lymphedema in transgenic mice expressing soluble VEGF receptor-3. Nat. Med. 7:199-205. doi:10.1038/84651

Mäkinen, T., R.H. Adams, J. Bailey, Q. Lu, A. Ziemiecki, K. Alitalo, R. Klein, and G.A. Wilkinson. 2005. PDZ interaction site in ephrinB2 is required for the remodeling of lymphatic vasculature. Genes Dev. 19:397-410. doi:10.1101/gad.330105

Mellor, R.H., G. Brice, A.W. Stanton, J. French, A. Smith, S. Jeffery, J.R. Levick, K.G. Burnand, and P.S. Mortimer; Lymphoedema Research Consortium. 2007. Mutations in FOXC2 are strongly associated with primary valve failure in veins of the lower limb. Circulation. 115:1912-1920. doi:10 1161/CIRCULATIONAHA.106.675348

Mellor, R.H., C.E. Hubert, A.W. Stanton, N. Tate, V. Akhras, A. Smith, K.G. Burnand, S. Jeffery, T. Mäkinen, J.R. Levick, and P.S. Mortimer. 2010. Lymphatic dysfunction, not aplasia, underlies Milroy disease. Microcirculation. 17:281296. doi:10.1111/j.1549-8719.2010.00030.x

Mesri, E.A., E. Cesarman, and C. Boshoff. 2010. Kaposi's sarcoma and its associated herpesvirus. Nat. Rev. Cancer. 10:707-719. doi:10.1038/ $\operatorname{nrc} 2888$

Miteva, D.O., J.M. Rutkowski, J.B. Dixon, W. Kilarski, J.D. Shields, and M.A. Swartz. 2010. Transmural flow modulates cell and fluid transport functions of lymphatic endothelium. Circ. Res. 106:920-931. doi:10.1161/ CIRCRESAHA.109.207274 
Mouta-Bellum, C., A. Kirov, L. Miceli-Libby, M.L. Mancini, T.V. Petrova, L. Liaw, I. Prudovsky, P.E. Thorpe, N. Miura, L.C. Cantley, et al. 2009. Organspecific lymphangiectasia, arrested lymphatic sprouting, and maturation defects resulting from gene-targeting of the PI3K regulatory isoforms p85alpha, p55alpha, and p50alpha. Dev. Dyn. 238:2670-2679. doi:10 $1002 /$ dvdy. 22078

Muthuchamy, M., A. Gashev, N. Boswell, N. Dawson, and D. Zawieja. 2003. Molecular and functional analyses of the contractile apparatus in lymphatic muscle. FASEB J. 17:920-922.

Nilsson, I., F. Bahram, X. Li, L. Gualandi, S. Koch, M. Jarvius, O. Söderberg, A. Anisimov, I. Kholová, B. Pytowski, et al. 2010. VEGF receptor 2/-3 heterodimers detected in situ by proximity ligation on angiogenic sprouts. EMBO J. 29:1377-1388. doi:10.1038/emboj.2010.30

Norrmén, C., K.I. Ivanov, J. Cheng, N. Zangger, M. Delorenzi, M. Jaquet, N. Miura, P. Puolakkainen, V. Horsley, J. Hu, et al. 2009. FOXC2 controls formation and maturation of lymphatic collecting vessels through cooperation with NFATc1. J. Cell Biol. 185:439-457. doi:10.1083/jcb.200901104

Ny, A., M. Koch, M. Schneider, E. Neven, R.T. Tong, S. Maity, C. Fischer, S. Plaisance, D. Lambrechts, C. Héligon, et al. 2005. A genetic Xenopus laevis tadpole model to study lymphangiogenesis. Nat. Med. 11:998-1004.

Pacheco-Rodriguez, G., F. Kumaki, W.K. Steagall, Y. Zhang, Y. Ikeda, J.P. Lin, E.M. Billings, and J. Moss. 2009. Chemokine-enhanced chemotaxis of lymphangioleiomyomatosis cells with mutations in the tumor suppressor TSC2 gene. J. Immunol. 182:1270-1277.

Pennisi, D., J. Bowles, A. Nagy, G. Muscat, and P. Koopman. 2000. Mice null for sox 18 are viable and display a mild coat defect. Mol. Cell. Biol. 20:93319336. doi:10.1128/MCB.20.24.9331-9336.2000

Petrova, T.V., T. Mäkinen, T.P. Mäkelä, J. Saarela, I. Virtanen, R.E. Ferrell, D.N. Finegold, D. Kerjaschki, S. Ylä-Herttuala, and K. Alitalo. 2002. Lymphatic endothelial reprogramming of vascular endothelial cells by the Prox-1 homeobox transcription factor. EMBO J. 21:4593-4599. doi:10.1093/emboj/cdf470

Petrova, T.V., T. Kärpänen, C. Norrmén, R. Mellor, T. Tamakoshi, D. Finegold, R. Ferrell, D. Kerjaschki, P. Mortimer, S. Ylä-Herttuala, et al. 2004. Defective valves and abnormal mural cell recruitment underlie lymphatic vascular failure in lymphedema distichiasis. Nat. Med. 10:974-981. doi:10 $1038 / \mathrm{nm} 1094$

Pflicke, H., and M. Sixt. 2009. Preformed portals facilitate dendritic cell entry into afferent lymphatic vessels. J. Exp. Med. 206:2925-2935. doi:10 .1084/jem.20091739

Radhakrishnan, K., and S.G. Rockson. 2008. Gorham's disease: an osseous disease of lymphangiogenesis? Ann. NY Acad. Sci. 1131:203-205. doi:10 .1196/annals.1413.022

Rockson, S.G. 2001. Lymphedema. Am. J. Med. 110:288-295. doi:10.1016/ S0002-9343(00)00727-0

Rockson, S.G. 2008. Secondary lymphedema: is it a primary disease? Lymphat. Res. Biol. 6:63-64. doi:10.1089/lrb.2008.6201

Sabin, F.R. 1902. On the origin of the lymphatic system from the veins and the development of the lymph hearts and thoracic duct in the pig. Am. J. Anat. 1:367-391. doi:10.1002/aja.1000010310

Saharinen, P., H. Helotera, J. Miettinen, C. Norrmen, G. D’Amico, M. Jeltsch, T. Langenberg, W. Vandevelde, A. Ny, M. Dewerchin, et al. 2010. Claudinlike protein 24 interacts with the VEGFR-2 and VEGFR-3 pathways and regulates lymphatic vessel development. Genes Dev. 24:875-880. doi:10.1101/gad.565010

Sato, T., K. Seyama, H. Fujii, H. Maruyama, Y. Setoguchi, S. Iwakami, Y. Fukuchi, and O. Hino. 2002. Mutation analysis of the TSC1 and TSC2 genes in Japanese patients with pulmonary lymphangioleiomyomatosis. J. Hum. Genet. 47:20-28. doi:10.1007/s10038-002-8651-8

Schacht, V., M.I. Ramirez, Y.K. Hong, S. Hirakawa, D. Feng, N. Harvey, M. Williams, A.M. Dvorak, H.F. Dvorak, G. Oliver, and M. Detmar. 2003. T1alpha/podoplanin deficiency disrupts normal lymphatic vasculature formation and causes lymphedema. EMBO J. 22:3546-3556. doi:10 .1093/emboj/cdg342

Seyama, K., T. Kumasaka, M. Kurihara, K. Mitani, and T. Sato. 2010. Lymphan gioleiomyomatosis: a disease involving the lymphatic system. Lymphat. Res. Biol. 8:21-31. doi:10.1089/1rb.2009.0018

Sleeman, J., A. Schmid, and W. Thiele. 2009. Tumor lymphatics. Semin. Cancer Biol. 19:285-297. doi:10.1016/j.semcancer.2009.05.005

Srinivasan, R.S., M.E. Dillard, O.V. Lagutin, F.J. Lin, S. Tsai, M.J. Tsai, I.M. Samokhvalov, and G. Oliver. 2007. Lineage tracing demonstrates the venous origin of the mammalian lymphatic vasculature. Genes Dev. 21:2422-2432. doi:10.1101/gad.1588407

Srinivasan, R.S., X. Geng, Y. Yang, Y. Wang, S. Mukatira, M. Studer, M.P. Porto, O. Lagutin, and G. Oliver. 2010. The nuclear hormone receptor CoupTFII is required for the initiation and early maintenance of Prox1 expression in lymphatic endothelial cells. Genes Dev. 24:696-707. doi:10 $1101 / \operatorname{gad} .1859310$
Suzuki-Inoue, K., O. Inoue, G. Ding, S. Nishimura, K. Hokamura, K. Eto, H. Kashiwagi, Y. Tomiyama, Y. Yatomi, K. Umemura, et al. 2010. Essential in vivo roles of the C-type lectin receptor CLEC-2: embryonic/neonatal lethality of CLEC-2-deficient mice by blood/lymphatic misconnections and impaired thrombus formation of CLEC-2-deficient platelets. J. Biol. Chem. 285:24494-24507. doi:10.1074/jbc.M110.130575

Tammela, T., and K. Alitalo. 2010. Lymphangiogenesis: Molecular mechanisms and future promise. Cell. 140:460-476. doi:10.1016/j.cell.2010.01.045

Taniguchi, K., R. Kohno, T. Ayada, R. Kato, K. Ichiyama, T. Morisada, Y. Oike, Y. Yonemitsu, Y. Maehara, and A. Yoshimura. 2007. Spreds are essential for embryonic lymphangiogenesis by regulating vascular endothelial growth factor receptor 3 signaling. Mol. Cell. Biol. 27:4541-4550. doi:10.1128/MCB.01600-06

Uhrin, P., J. Zaujec, J.M. Breuss, D. Olcaydu, P. Chrenek, H. Stockinger, E. Fuertbauer, M. Moser, P. Haiko, R. Fässler, et al. 2010. Novel function for blood platelets and podoplanin in developmental separation of blood and lymphatic circulation. Blood. 115:3997-4005. doi:10.1182/ blood-2009-04-216069

van Steensel, M.A., R.J. Damstra, M.V. Heitink, R.S. Bladergroen, J. Veraart, P.M. Steijlen, and M. van Geel. 2009. Novel missense mutations in the FOXC2 gene alter transcriptional activity. Hum. Mutat. 30:E1002-E1009. doi:10.1002/humu.21127

Wang, H.W., M.W. Trotter, D. Lagos, D. Bourboulia, S. Henderson, T. Mäkinen, S. Elliman, A.M. Flanagan, K. Alitalo, and C. Boshoff. 2004. Kaposi sarcoma herpesvirus-induced cellular reprogramming contributes to the lymphatic endothelial gene expression in Kaposi sarcoma. Nat. Genet. 36:687-693. doi:10.1038/ng1384

Wang, Y., M. Nakayama, M.E. Pitulescu, T.S. Schmidt, M.L. Bochenek, A. Sakakibara, S. Adams, A. Davy, U. Deutsch, U. Lüthi, et al. 2010. Ephrin-B2 controls VEGF-induced angiogenesis and lymphangiogenesis. Nature. 465:483-486. doi:10.1038/nature09002

Wigle, J.T., and G. Oliver. 1999. Prox1 function is required for the development of the murine lymphatic system. Cell. 98:769-778. doi:10.1016/ S0092-8674(00)81511-1

Wigle, J.T., K. Chowdhury, P. Gruss, and G. Oliver. 1999. Prox1 function is crucial for mouse lens-fibre elongation. Nat. Genet. 21:318-322. doi:10 $.1038 / 6844$

Wirzenius, M., T. Tammela, M. Uutela, Y. He, T. Odorisio, G. Zambruno, J.A. Nagy, H.F. Dvorak, S. Ylä-Herttuala, M. Shibuya, and K. Alitalo. 2007. Distinct vascular endothelial growth factor signals for lymphatic vessel enlargement and sprouting. J. Exp. Med. 204:1431-1440. doi:10 .1084/jem.20062642

Xu, Y., L. Yuan, J. Mak, L. Pardanaud, M. Caunt, I. Kasman, B. Larrivée, R. Del Toro, S. Suchting, A. Medvinsky, et al. 2010. Neuropilin-2 mediates VEGF-C-induced lymphatic sprouting together with VEGFR3. J. Cell Biol. 188:115-130. doi:10.1083/jcb.200903137

Yamazaki, T., Y. Yoshimatsu, Y. Morishita, K. Miyazono, and T. Watabe. 2009. COUP-TFII regulates the functions of Prox1 in lymphatic endothelial cells through direct interaction. Genes Cells. 14:425-434. doi:10.1111/ j.1365-2443.2008.01279.x

Yaniv, K., S. Isogai, D. Castranova, L. Dye, J. Hitomi, and B.M. Weinstein. 2006. Live imaging of lymphatic development in the zebrafish. Nat. Med. 12:711-716. doi:10.1038/nm1427

Yoo, J., J. Kang, H.N. Lee, B. Aguilar, D. Kafka, S. Lee, I. Choi, J. Lee, S. Ramu, J. Haas, et al. 2010. Kaposin-B enhances the PROX1 mRNA stability during lymphatic reprogramming of vascular endothelial cells by Kaposi's sarcoma herpes virus. PLoS Pathog. 6: e1001046. doi:10.1371/journal .ppat. 1001046

Yu, J.J., V.A. Robb, T.A. Morrison, E.A. Ariazi, M. Karbowniczek, A. Astrinidis, C. Wang, L. Hernandez-Cuebas, L.F. Seeholzer, E. Nicolas, et al. 2009. Estrogen promotes the survival and pulmonary metastasis of tuberin-null cells. Proc. Natl. Acad. Sci. USA. 106:2635-2640. doi:10 .1073/pnas.0810790106

Yuan, L., D. Moyon, L. Pardanaud, C. Bréant, M.J. Karkkainen, K. Alitalo, and A. Eichmann. 2002. Abnormal lymphatic vessel development in neuropilin 2 mutant mice. Development. 129:4797-4806.

Zawieja, D.C. 2009. Contractile physiology of lymphatics. Lymphat. Res. Biol. 7:87-96. doi:10.1089/lrb.2009.0007

Zhang, L., F. Zhou, W. Han, B. Shen, J. Luo, M. Shibuya, and Y. He. 2010. VEGFR-3 ligand-binding and kinase activity are required for lymphangiogenesis but not for angiogenesis. Cell Res. 20:1319-1331. doi:10 $.1038 / \mathrm{cr} .2010 .116$

Zhou, F., Z. Chang, L. Zhang, Y.K. Hong, B. Shen, B. Wang, F. Zhang, G. Lu, D. Tvorogov, K. Alitalo, et al. 2010. Akt/Protein kinase B is required for lymphatic network formation, remodeling, and valve development. Am. J. Pathol. 177:2124-2133. doi:10.2353/ajpath.2010.091301 